\title{
Medical Ethics Versus Governmental Objectives
}

\author{
Samuel J. Stratton, MD, MPH
}

In this issue of Prehospital and Disaster Medicine (PDM), two papers are presented that address medical ethics during conflict from the humanitarian perspective. The papers by Dougherty and co-authors and by Burkle and co-authors explore the ethical paradoxes facing medical professionals in the setting of government-sponsored conflict.

The ethical practice of medicine has undergone refinement since the end of World War II. Initially, support for the need to have accepted international medical ethical standards was based on medical experimental and treatment injustices that occurred during World War II. It is important to recognize that ongoing medical atrocities followed World War II, with US syphilis experiments conducted until 1972 in Tuskegee, Alabama, in which effective syphilis treatment was purposely withheld from a vulnerable population to "study" the natural progression of the disease. Additionally, despite recognition of the potential dangers of radiation exposure after nuclear bomb blasts in Japan, military physicians in both the US and Russia allowed purposeful exposure of unsuspecting military personnel to radiation during nuclear explosion experiments conducted during the decade of the 1950s. These modern-era ethical breaches illustrate the need for defined international ethics standards.

Medical ethics is a system of moral behavior that demands that medical professionals provide medical services that meet community standards, with respect for human dignity and rights without consideration of station in life. ${ }^{1}$ Ironically, well-defined codes of conduct for national governments are not available. A search of the United Nations web site shows a number of ethics statements for personnel, but not a defined ethics code for government entities. The closest that world governments have come to delineating ethics in governance is the Geneva Convention, which represents treaties adopted to define international agreements that apply in times of armed conflict.

In essence, government represents and is the community which it governs. Whether elected or non-elected, government protects citizens, promulgates laws for social order, and collects taxes from the community to provide community services. Government is a reflection of the community governed, particularly a reflection of those with power and influence within the community. Arguably, the actions of a government reflect the morals of the leaders and community that form that government.

This leads to the issue of the force-feeding of Guantanamo detainees. As of the beginning of October 2013, there were 15 Guantanamo detainees participating in a hunger strike to protest their indefinite imprisonment. The medical ethics of force-feeding is discussed in depth by Dougherty and Burkle in their papers published in this issue of PDM. Also, on October 18, 2013, a US Federal Appeals Court in Washington heard legal arguments that challenge the force-feeding. In essence, the force-feedings are an enormous challenge to the moral and ethical foundations of the US medical and legal professions. Yet, government proceeds with the force-feedings, despite the ethical dilemmas into which participating citizens who are medical professionals are being forced.

In the 2008 US elections, the current government leadership promised closure of Guantanamo and fair public trials for the detainees. Five years later, Guantanamo detainees remain in suspended imprisonment without the opportunity to provide evidence of innocence or hope of returning to their homeland and families. Hunger striking is a logical action in such a desperate situation, and an action a mentally competent person has a human right to pursue. Rather than honor that human right and address the underlying issue of indefinite imprisonment without recourse, government has taken the ethically questionable action of force-feeding-an action that many would consider torture. In taking such an action, government also forces medical staffs to conduct themselves in an ethically questionable manner that may be a violation of the Geneva Convention.

In Syria, world governments also have failed to meet reasonable moral and ethical standards. The almost certain use of chemical weapons on a civilian population that included the most vulnerable of non-combatants (children and elderly) is without doubt a war crime of international concern. Yet, because of political interests, little is to be done by world governments to address the crime. Rather, world governments have accepted an approach that will allow stalling by war criminals, and likely not remove the threat of future such attacks on innocents.

It is important to understand medical ethics principles that are accepted throughout the world. Unspoken is that without medical ethical standards, the people of the world would have little trust in the medical professions. Established medical ethics should be accepted, rather than rejected when convenient, by world governments.

Ultimately, as members of the communities represented by involved governments, citizens in the community are the true wrongdoers in Guantanamo and Syria. Government is a reflection of the community it represents and members of that community share responsibility for their government's unethical acts.

Reference

1. Williams JR, ed. Medical Ethics Manual. 2nd ed. Ferney-Voltaire Cedex, France:

World Medical Association, Inc.; 2009. 